\title{
Study on Team Construction of Ideological and Political Education Management in Colleges and Universities
}

\author{
Yang Zhang ${ }^{1, \text { a }}$ \\ ${ }^{1}$ College of Information Technology and Media, Beihua University, Jilin 132013, China. \\ ayang_zhang001@126.com
}

Keywords: team construction, ideological and political education management, colleges and universities.

\begin{abstract}
The general problems existing in the t team construction of the discipline of ideological and political education management in colleges and universities is analyzed for exploring its nature, defining its concept, and making distinction between itself and its relative concepts. Then the team construction of ideological and political education is elaborated from the two levels, namely, the composition of the teaching staff as a whole and the qualities. In this paper, the routes and model of team construction in the new era are proposed from the angles of development and innovation. The results would surely play an active role in strengthening and promoting the team construction of ideological and political education management.
\end{abstract}

\section{Introduction}

Decision-making functions is the primary function of the ideological and political education management team. Ideological and political education management team decision-making, is to decide on the ideological and political education in important issues, specifically, it is to achieve the set of ideological and political goals, a number of possible plans, choose the best course of action programs. Decision-making functions has a very important role in the ideological and political education management team. First, it is the starting point for ideological and political education management activities. Generally, colleges and universities ideological and political education management activities, always in accordance with objective, clear what to do, do not do and how to do so on a range of issues, which would be the decision-making. No decision-making, the ideological and political education there can be no management activities Colleges began; second, it is the key and core of ideological and political education management process. Ideological and political education management process to plan, organize and control revolves around the decision to launch, leaving the decision, other management activities to be without purpose and criterion; third, scientific decision-making is to improve the ideological and political education management efficiency and effectiveness guarantee. With the scientific decision-making, we will have the right and efficient organizational behavior, once the decision is wrong and will cause organizational behavior deviate from the correct track, and caused a serious waste of resources of ideological and political education.

Ideological and political education management team decisions according to different situations can be classified as follows: First, according to the decision-making body, can be divided into individual and collective decision-making ideological and political education management in the collective leadership and individual responsibility in the system of combining. ideological and political education, ideological and political relations Where major issues of education and overall development direction should be from the collective decision-making, individual leaders can not arbitrarily arbitrary. In the collective decision-making, the College Party Committee is the highest decision-making body of the College; and the daily work of a specific problem or need for emergency treatment, the division responsible for individual leaders should be to the party's cause highly responsible spirit, make timely decisions ; second, according to the scope and extent affected by the decision, it can be divided into general and strategic decision making. Strategic decision means determines the direction of development of ideological and political education to address major issues of school decisions. It refers to the general decision-making to solve the ideological and political education process locally or individual issues decisions. General decision should obey and 
serve the strategic decision-making, but also through a series of strategic decisions to reflect general decision-making and the progressive realization; third, according to the nature of decision-making, decision-making can be divided into conventional and unconventional decisions. Routine decision means that the decision to resolve the frequently recurring question.

\section{Ideological and political education management team scientific decision-making fundamentals}

Ideological and political education management team of University ideological and political education management of scientific decision-making, must follow the following principles: First, the information principle. Information is the prerequisite and basis for decision-making. To carry out ideological and political education of scientific decision-making, it is necessary to have accurate, reliable, comprehensive information systems thinking and decision-making related; second, forecasting principles. Decisions are future-oriented behavior, correct decision or not, it depends on the correct level of future events, changes made to the consequences of the judgment. Therefore, in the decision-making process must be used to predict the theoretical and technical methods of scientific forecasting, to provide scientific decision-making basis; third, practical principles. Decisions must be able to perform. Ideological and political education in colleges and universities in the decision, we must seek truth from facts, proceeding from reality, according to the social environment, and the development of the ideological reality of the conditions and the reality of the school staff and students to make decisions may make decisions based on feasible and reliable basis; Fourth, the principle of system theory and methods of system engineering decision-making is an important guarantee for scientific decision-making in the ideological and political education decision-making colleges and universities, ideological and political education to involve the entire school as a system, with the system as a whole goal as the core, to optimize the overall objective yardstick; all decisions on ideological and political education, we must put the whole system to weigh and evaluate the combined effect; pay attention to ideological and political education school system all sides at all levels mutual relations, in order to achieve balance and overall system optimization; fifth, the principle of merit. Decision actually be selected from among two or more action programs. Therefore, in the decision-making process, it must be solved on the various issues raised NAP system analysis and synthesis, based on the various options and carefully compare the conditions needed to compare various programs, brought effects and consequences, to choose the best option; sixth, feedback and implement the principles of decision-making always cause some operational consequences of the decision feedback is used to test the decision-making practice that, according to the changed circumstances and the practice of feedback case, the original decision to make corresponding adjustments to make decision-making more perfect.

Ideological and political education management team for scientific decision-making, scientific decision-making procedures must be followed. Decision-making process comprising the steps of several interrelated: first, identify problems and problem refers to the gap between the actual situation and the situation should any decisions are found from the beginning of the problem, identify problems in a timely manner is correctly thought. the most important part of political education decision-making; second, to determine the target. When the problem is found, it is necessary to solve the problem to determine the result to be achieved, which is targeting. Targeting ideological and political education is an important part of the decision. All decisions of the program revolves around a predetermined target and design, target of errors inevitably lead to wrong decisions. Correctly determine the target, first, must be based on the fundamental purpose of the Party's basic line and education policy and ideological and political education as a guide, students and staff from the idea of reality, inherent laws to staff and students thought was expanding. Secondly, the meaning must be clear objectives, content to specific targets to quantify the scale and clear metrics; Third, develop programs. After the target is determined, it is necessary to develop problem-solving, achieve the goal of various possible options to choose from.

Develop programs must focus on the decision-making objectives, requirements for clear decision-making objectives set commenced, various alternatives proposed route taken, measures 
must be different from each other, we can not be very much the same; the fourth, program evaluation. After prepare options, based on a predetermined target needs and evaluation criteria to achieve this goal, the pros and cons of various options, conduct rigorous argument, repeated comparisons and overall balance, so as to provide a scientific basis for the most optimal option. In program evaluation should focus on the feasibility of various options make analysis. Including: program development according to whether there is sufficient and practical implementation of the program can achieve the desired effect which problems and difficulties as well as the presence or absence of the corresponding preventive and remedial measures may occur after the implementation of the program, and so on; fifth, plan option. Choose the best program is the key decision-making processes. The selection criteria is value: most conducive to achieve the established goals; reflects the maximum benefits; easy to implement. Of course, most programs only under certain conditions, with respect to the various alternatives in terms, not absolute.

\section{Situation Team Construction of Ideological and Political Education in China}

From our ranks of cadres situation, with the deepening of reform and opening up and socialist modernization drive, Cadres facing many new situations in the past did not encounter new problems, these problems are: First, ideological and political qualities declined. Specific performance: contempt of political theory, ideals and beliefs shaken, not political stand firm, declined sense of purpose, political sensitivity and discernment is not strong. The second is that breeds corruption, repeated. Third, the presence of defects in the current cadre and personnel system. Such cadres can not be under, you can go up not down, to no return; difficult talents come to the fore; malpractices on difficult to effectively overcome the like. From the field of higher education, the ideological and political education management team of the universities, it should be said, we have made significant achievements. But from a practical point of view look at, easy to find, ideological and political education Construction of College management team there are still some problems, the most prominent: the ideological and political education management team of the universities lack the integrity of scientific planning, ideological and political education management team overall combat carrying ability and the task is not coordinated, the overall quality of the ideological and political education and a positive image of the management team needs to be further improved, ideological and political education management team nurture and safeguard mechanism is not sound.

In recent years, colleges and universities ideological and political education more emphasis on middle management ranks of cadres, the selection of a group of young academic backbone of the ideological and political education took to the middle management positions. Their advantage is a higher level of education and the level of professional titles, thinking keen, full of pioneering spirit, and the situation of the first line of research has personal experience of teaching. This is helping to strengthen the close ties of cadres and teachers, among students, in favor of ideological and political education management and education of unity; but on the other hand, due to the "Double Shoulder Task" cadres set several roles in one, and is generally considered the teaching and research work is the "root", so, without exception, will be the main energy into teaching and research work, thus resulting in "hard hand, a soft" situation. Meanwhile, the young academic backbone of the ideological and political education took middle management positions in the future, the lack of clear guiding ideology and reform ideas in practice, there is a lack of policy at the level of theory, macro-control ability, leadership and so on. Specializing in the management of ideological and political education of the apparent lack of backbone.

\section{Summary}

The basic contents of the scientific development concept is a comprehensive, coordinated and sustainable development, adhere to a comprehensive, coordinated and sustainable development of the concept of ideological and political education to improve the overall quality of the management team is the proper meaning and the inherent requirements of higher education. Adhere to a comprehensive 
development, strengthen the cultivation of ideological and political education management team, enhance the overall level of ideological and political education of the management team is the comprehensive development of the major institutions of higher learning task must be completed. I think that universities should adhere to comprehensive development, strengthen the cultivation of ideological and political education management team, should pay particular attention to two aspects: First, pay special attention to ideological and political education of teachers' morality managers and establish a management education good atmosphere. Ideological and political education manager is the dominant force in higher education and management, the manager of the ideological and political education ideological and political quality and morality of the managed object has a direct influence and appeal. Ideological and political education is a special professional managers, management practice their morality, teaching style and charisma needed to get through day after day, year after year. Therefore, the need to actively explore new ways to strengthen the ideological and political education of teachers' morality management team to guide the ideological and political education administrators to establish a correct outlook on education and management concept, with a solid and rigorous work style and superb management skills to complete the Management and Education people's mission; the second is to pay special attention to the overall quality of the ideological and political education management team, the formation of expert groups and innovative management team competitive. Through centralized training, overseas training, testing and training, etc. Cultivation of thinking and political education of professional quality management team; academic and professional titles should be distinguished. However, higher education can not become no assistant, no education, hone lecturer, then associate professor, highly educated people can not go through the necessary teaching practice any direct comment senior title.

\section{References}

[1] Oriole, Colleges and Universities in Teacher Training and Management, Zhejiang University of Science and Technology, June 2003 No. 2

[2] Blue Yan, strengthen ideological and political education of workers, team building and management of Higher, 20031

[3] Qi Guichen, strengthen the moral construction of university part-time teachers, Liaoning Higher Education Research, 19943

[4] Liu Xintang, etc., on the meaning and mechanism construction of specialized college counselors, ideological education research, 20076

[5] Wang Dongmei, the issue of part-time Faculty in American Universities and Countermeasures EDUCATION EXPLORATION, 2007, No. 2, 80-83

[6] Han-chi, to talk about the establishment of a professional and ideological and political education teachers, education and occupation, 200614

[7] Tian Wei et al., Ideological and political work full-time Counselors exploration and practice, theory, 2006.5

[8] Luo fire cases, strengthen the ideological and political education work team building, Guangxi University (Philosophy and Social Science), 19925

[9] College Marxism communication strategy Suxing Hong, Liu Ji. Microblogging era. EDUCATIONAL research, 2012, 09, 27-30. 